\title{
Reading Day (One Book One Person): Gerakan Literasi Sekolah Sebagai Perwujudan Budaya Baca di Sekolah Sukma Bangsa Lhokseumawe
}

\author{
Ernawati \\ Universitas Islam Negeri Sunan Kalijaga \\ qisthyblog@gmail.com
}

\begin{abstract}
Abstrak
Penelitian ini bertujuan untuk mendeskrispikan pelaksanaan Gerakan Literasi Sekolah (GLS) Sukma Bangsa Lhokseumawe. Jenis penelitian ini deskriptif kualitatif yang menggambarkan fenomena atau objek implementasi program Gerakan Literasi Sekolah. Teknik pengumpulan data melalui observasi, wawancara dan dokumentasi. Keabsahan data menggunakan triangulasi sumber, teknik dan waktu. Hasil penelitian bahwa pelaksanaan GLS di Sekolah Sukma Bangsa Lhokseumawe dengan Reading Day (One Book One Person). Program menjadi salah satu program pembiasaan membaca yang diterapkan di Sekolah Sukma Bangsa Lhokseumawe. Model membaca buku (One Book One Person) bukan buku pelajaran selama 15 menit dikembangkan antara guru dan pustakawan yang melakukan kolaborasi bersama. Strategi yang dilakukan dengan sepuluh cara yaitu membentuk panitia GLS, strategi sosialisasi program, siswa dan guru memiliki satu buku bacaan, pelibatan seluruh elemen sekolah, membuat papan afirmasi, menentukan target bacaan, mempresentasikan buku yang dibaca, mengevaluasi kegiatan, memberikan apresiasi, mengumpulkan hasil tulisan.
\end{abstract}

\section{Pendahuluan}

Membaca adalah salah satu pintu untuk mencari informasi-informasi yang dapat bermanfaat dalam kehidupan, dengan aktif membaca buku juga mampu mengasah ketrampilan membaca. Hasil membaca adalah dengan menulis atau mencatat dari apa yang dibaca. Selanjutnya dari proses itu dapat pula menambah pengetahuan dengan menganalisa dan memahami bacaan, sehingga mampu berpikir kritis. (Aziz, 2017)

Bagi sebagian orang, membaca adalah sesuatu hal mudah namun sulit diterapkan dan dilakukan. Kegiatan membaca dianggap hal yang sangat membosankan. Orang lebih suka menonton televisi dan mendengarkan musik melalui media lain. Mewujudkan budaya literasi tidak semudah membalikkan telapak tangan. Jepang saja membutuhkan waktu sekitar 30 tahun untuk mewujudkan budaya membaca dengan membuat

\author{
Kata Kunci : \\ Gerakan Literasi Sekolah \\ Reading Day \\ One book One Person
}

salah satu kebijakan membaca 10 menit sebelum kegiatan belajar sekolah dimulai. Tak cukup dengan kebijakan tersebut, kebijakan memperbanyak toko buku juga dilakukan oleh pemerintah Jepang disertai dengan kegiatan membaca gratis (tachiyomi) di toko buku. Meskipun dalam menumbuhkan budaya literasi banyak mengorbankan hal-hal yang menguras pikiran, tenaga bahkan dana yang tidak sedikit demi menuju proses budaya literasi membaca. (IKAPI, 2018)

Penerapan budaya baca seyogyanya dimulai sejak dini, dan berawal dari lingkungan keluarga terutama peranan orang tua. Selain itu institusi pendidikan juga perlu memberi perhatian demi tujuan mencerdaskan budaya literasi ini. Melalui pendidikan, sarana membentuk masa depan suatu bangsa merupakan tolok ukur dalam mewujudkan masyarakat berbudaya literasi. Melalui pendidikan, setiap orang akan melalui 
sebuah proses transfer of value dari generasi ke generasi yang baru. Tumbuhnya nilai-nilai gemar membaca dan menulis berasal dari lembaga yang mengimplementasikannya melalui pendidikan. Baik dari tingkat pemula sampai ke jenjang pendidikan tinggi. Budaya membaca menjadi sebuah rutinitas dan kewajiban, seandainya saja pendidikan menanamkan nilai-nilai budaya tersebut dalam pendidikan.

Supandi (2016:3), budaya literasi baca tulis yang seharusnya menjadi salah satu bagian dari sebuah pengembangan diri belum begitu digalakkan di sekolah. Hal ini terlihat dari fenomena dan realita yang ada, yaitu ketika bel istirahat sekolah berbunyi, sebagian besar siswa berhamburan menuju kantin sebagai tempat pilihan favorit untuk menghabiskan waktu sambil santai dari pada memilih perpustakaan sebagai tempat yang nyaman.

Hal tersebut tidak terjadi pada satu sekolah, namun hampir seluruh ruang lingkup pendidikan mengalami hal yang sama. Aktivitas membaca belum menjadi sebuah budaya yang melekat bagi kehidupan manusia terutama kalangan anak usia 7 sampai dengan 17 tahun. Human Development Indeks (HDI) menyebutkan Indonesia berada pada urutan 60 dari 61 negara di dunia yang literasinya begitu rendah dibandingkan Jepang. Fakta ini sangatlah memprihatinkan, apalagi jika melihat bahwa dari segi penilaian infrastruktur, peringkat Indonesia berada di bawah negara Eropa. (Gewati, 2016)

Melihat kondisi demikian, pemerintah melakukan sebuah upaya dalam menumbuhkan budaya literasi peserta didik yang dikemukakann oleh Mantan Mendikbud Anis Baswedan mencetuskan program Literasi Sekolah (GLS). Program ini tertuang dalam Permendikbud RI Nomor 23 tahun 2015 tentang penumbuhan Budi Pekerti. Program ini bertujuan untuk menumbuhkan budaya literasi di Sekolah. Salah satu kegiatan dalam program GLS (Gerakan Literasi Sekolah) ini adalah membaca buku non pelajaran selama 15 menit sebelum pelajaran dimulai. Kegiatan ini dilaksanakan untuk menumbuhkan minat baca peserta didik serta meningkatkan keterampilan membaca agar pengetahuan dapat dikuasai secara lebih baik. Materi bacaan dalam kegiatan ini adalah bacaan berisi nilai-nilai budi pekerti, berupa kearfian lokal, nasional dan global yang disampikan sesuai dengan taraf peserta didik.

Melihat tujuan dan pentingnya program GLS, sekolah sebagai satuan pendidikan harus mendukung program pemerintah tersebut, dengan menerapkan budaya membaca untuk menciptakan generasi gemar membaca. Sekolah memiliki peran dalam mengembangkan kemampuan siswanya, dengan berbagai kegiatan program membaca disesuaikan dengan sistem pembelajaran yang ada.

Sekolah Sukma Bangsa merupakan salah satu sekolah yang berada pada tiga tingkatan dari mulai SD sampai dengan SMA di Lhokseumawe. Sekolah Sukma Bangsa berada dibawah naungan yayasan Sukma bersama Media Group bersumber dari Dompet Indonesia Menangis pasca Tsunami 2004 silam. Sebelum dikeluarkannya program GLS oleh pemerintah, sekolah ini telah menjalankan program kegiatan Reading Day bersama baik antar sesama siswa dan siwa bersama guru. Hal ini merupakan program literasi yang dikembangkan oleh Direktur Pendidikan Yayasan.

Program kegiatan Reading day (One Book One People) merupakan kegiatan wajib baca buku bagi setiap orang termasuk guru secara bersama baik antar sesama siswa dan siswa bersama guru dalam kegiatan pembelajaran sekolah maupun diluar lingkungan sekolah. Rutinitas ini dilakukan secara terus menerus karena sekolah ini merupakan sekolah dengan sistem Boarding School.

Kegiatan ini menjadi program unggulan bagi sekolah Sukma Bangsa dalam menumbuhkembangkan budaya baca, melek huruf dan melek informasi. Artikel ini akan 
mengkaji lebih dalam terkait dengan implementasi program Reading Day di Sekolah Sukma Bangsa Lhokseumawe dalam mendukung GLS.

\section{Metode Penelitian}

Penelitian ini termasuk dalam jenis penelitian deskriptifkualitatifyangmenggambarkanfenomena atau objek implementasi program Gerakan Literasi Sekolah. Jenis Penelitian ini menghasilkan data-data deskriptif berupa kata-kata tertulis yang merupakan gambaran dari perilaku seseorang atau fenomena yang diamati. Penelitian ini memperoleh hasil berupa gambaran pelaksanaan program reading day dalam Gerakan Literasi Sekolah di Sekolah Sukma Bangsa Lhokseumawe.

Penelitian ini dilakukan untuk melihat bagaimana reading day diimplementasikan sebagai perwujudan budaya program Gerakan Literasi Sekolah di Sekolah Sukma Bangsa sehingga kegiatan tersebut bertahan sampai sekarang. Program Gerakan Literasi Sekolah di Sekolah Sukma Bangsa Lhokseumawe ini diharapkan agar ini dapat menggambarkan pelaksanaan program reading day serta hasil dari diberlakukannya kegiatan tersebut yang terintegrasikan dengan GLS.

Subyek dalam penelitian di Sekolah Sukma Bangsa Lhokseumawe ini terdiri dari seorang kepala sekolah pertingkatnya, walikelas pertingkatnya, petugas perpustakaan, perwakilan siswa perkelasnya sebanyak 5 orang dan wali murid pertingkatannya masing-masing 1 orang.

Obyek dalam penelitian ini adalah segala hal yang berkaitan dengan impelementasi program Gerakan Literasi Sekolah di masing-masing sekolah. Persepsi, aktifitas dan perilaku warga sekolah merupakan contoh obyek dalam penelitian ini. Data tentang obyek ini diperoleh dari keterangan subyek penelitian dan dari data lain yang diperoleh peneliti. Teknik pengumpulan data yang digunakan oleh peneliti dalam mendapatkan data yang objektif yaitu melalui observasi, wawancara dan dokumentasi. Data yang dikumpulkan akan dianalisis dan dilakukan penarikan kesimpulan oleh peneliti sesuai dengan isi penelitian.

\section{Pembahasan}

\subsection{Gerakan Literasi Sekolah (GLS)}

Gerakan Literasi sekolah merupakan salah satu program Kemendikbud RI. Program ini dicetuskan oleh mantan Mendikbud RI Anies Baswedan yang mana program ini lahir untuk memperkuat Permendikbud RI nomor 23 Tahun 2015 tentang penumbuhan Budi Pekertiyang salah satunya adalah upaya penumbuhan budaya literasi pada siswa dengan kegiatan membaca buku non pelajaran selama 15 menit sebelum pembelajaran kelas dimulai. Oleh (Endang : 2016) menjelaskan bahwa kegiatan GLS dilaksanakan untuk menumbuhkan minat baca peserta didik serta meningkatkan ketrampilan membaca agar pengetahuan dapat dikuasai secara lebih baik.

Imelda (2017) juga menyatakan tentang Gerakan Literasi Sekolah dimaknai sebagai upaya yang dilakukan secara menyeluruh untuk menjadikan sekolah sebagai organisasi pembelajaran yang warganya literat sepanjang hayat melalui pelibatan publik.

\subsection{Membangun Gerakan Literasi Sekolah}

Kegiatan GLS sebagai usaha menumbuhkan budaya baca tulis bisa berupa seminar/workshop, pengembangan perpustakaan, lomba dalam hal baca tulis, jumpa dengan penulis dan bedah buku, penghargaan bagi siswa dan guru yang aktif dan kreatif melakukan GLS dengan konsisten, serta pameran (Kemendikbud). Sebagaimana sudah disebutkan bahwa sekolah merupakan langkah awal dalam gerakan literasi di sekolah. Maka, diperlukannya langkah ataupun strategi untuk menciptakan budaya literasi yang baik di sekolah, diantaranya :

a. Menciptakan lingkungan fisik yang ramah literasi

Lingkungan fisik menjadi aspek penting yang harus dibangun karena lingkungan 
fisik merupakan yang pertama dilihat oleh anak. Untuk dapat menumbuhkan budaya literasi, sekolah harus menciptakan lingkungan fisik yang ramah dan kondusif. Lingkungan tersebut dapat dibangun dengan memajang karya siswa di berbagai area sekolah serta memberi kesempatan bagi siswa lain untuk dapat berkarya. Hal ini sebagai bentuk penghargaan pada siswa dan dapat menjadi insentif bagi siswa untuk semakin termotivasi untuk membaca. Upaya lain yang dapat dilakukan oleh sekolah adalah dengan menyediakan fasilitas penunjang seperti pojok baca, perpustakaan mini, mading dan reading corner.

b. Menciptakan lingkungan sosial dan afektif sebagai modal komunikasi dan interaksi yang literat.

Lingkungan sosial dan afektif dibangun melalui model komunikasi dan interaksi seluruh komponen sekolah. Adanya pengakuan dan penghargaan atas capaian siswa merupakan salah satu upaya mewujudkan lingkungan sosial dan afektif. Capaian tersebut tidak dibatasi pada aspek akademik, namun juga nonakademik. Bentuk penghargaan pun dapat diarahkan kepada hal-hal yang dapat meningkatkan literasi siswa seperti pemberian buku sebagai hadiah serta sertifikat penghargaan sebagai apresiasi sekolah terhadap kegiatan literasi. Apresiasi kegiatan ini disampaikan kepada seluruh civitas akademik sebagai bentuk promosi bahwa kegiatan literasi ini mampu memberikan motivasi bagi seluruh pembaca untuk terus meningkatkan literasi bacanya. Literasi pun perlu menjadi warna dalam setiap perayaan dan kegiatan di sekolah sehingga dalam kegiatan seperti festival pendidikan dan bazaar buku tidak terlepas dari unsur budaya literasi.

c. Menciptakan sekolah sebagai lingkungan akademik yang literat.

Salah satu upaya dalam membangun sekolah sebagai lingkungan akademik yang literat adalah pemberian alokasi waktu bagi pembiasaan literasi seperti alokasi waktu 15 menit sebelum pembelajaran untuk membaca nyaring maupun membaca dalam hati. Untuk mendukung kegiatan ini, guru perlu diberi pelatihan agar dapat mendampingi siswa dalam setiap kegiatan pembiasan literasi serta dapat menjadi inspirasi bagi siswa.

Selain itu juga, adanya implementasi dengan model kolaborasi dalam mengintegrasikan kegiata di sekolah dengan perpustakaan. Salah satu promotor penggeraknya adalah guru dan pustakawan. Kebiasaan membaca tidak akan berjalan dengan baik seandainya tidak ada kolaborasi ataupun stakeholder dari sekolah untuk turut memulainya atau paling tidak menjadi contoh pertama dalam pengembangan gerakan literasi di sekolah.

\subsection{Penerapan Budaya Membaca}

Penerapan budaya membaca memang dimulai sejak dini dan berawal dari lingkungan keluarga terutama peranan orang tua, namun institusi pendidikan juga perlu memberi perhatian demi tujuan mencerdaskan budaya literasi ini. Melalui pendidikan, sarana membentuk masa depan suatu bangsa merupakan tolak ukur dalam mewujudkan masyarakat berbudaya literasi.

Budaya literasi yang seharusnya menjadi salah satu bagian dari sebuah pengembangan diri siswa belum begitu digalakkan di sekolah. Hal ini terlihat dari fenomena dan realita yang ada, yaitu ketika bel istirahat sekolah berbunyi, kebanyakan siswa berhamburan menuju kantin sebagai tempat pilihan favorit untuk menghabiskan waktu sambil santai dari pada memilih perpustakaan sebagai tempat 
yang nyaman (Supandi : 2016). Hal yang sama yang dilakukan oleh (Gewati : 2018) dalam penelitiannya menemukan fakta bahwa fenomena tersebut tidak terjadi pada satu sekolah, namun hampir seluruh ruang lingkup pendidikan mengalami hal yang sama.

Membaca berperan penting dalam setiap kehidupan karena berkembangnya pengetahuan yang diperoleh dengan membaca. Oleh karenanya, membaca perlu terus dikembangkan sebagai sebuah budaya dan warisan untuk generasi bangsa. Gerakan literasi di sekolah memperkuat gerakan dalam menumbuhkan budi pekerti sesuai dalam Peraturan Menteri Pendidikan dan Kebudayaan Nomor 13 Tahun 2015. Kegiatan "15" menit membaca buku fiksi dan pengembangan karakter sebelum kegiatan belajar mengajar dimulai disekolah". Kegiatan ini dilaksanakan dalam rangka menumbuhkembangkan minat baca tidak hanya peserta didik tetapi keterlibatan guru sebagai pendidik juga harus dimulai secara bersama-sama.

Sesuai dengan Dikmen Dikti terkait materi bacaan yang menjadi referensi pengetahuan berisi tentang nilai-nilai budi pekerti, berupa kearifan lokal, nasional dan global yang disampaikan sesuai tahap perkembangan peserta didik. Keterlibatan antara guru menjadi kompenen utama pendukung kegiatan gerakan literasi di sekolah, karena guru merupakan contoh, role atau model bagi peserta didiknya.

One Book One Person menjadi salah satu program unggulan yang diterapkan oleh sekolah Sukma dalam minat baca sebelum tercetusnya GLS tahun 2013. Program ini dikembangkan antara guru dan pustakawan yang melakukan kolaborasi bersama dalam menindaklanjuti pemikiran dari direktur pendidikan yayasan Sukma. Munculnya gerakan Literasi Sekolah, lebih kepada dukungan akan kegiatan One Book One Person yang sudah dilakukan oleh Sekolah Sukma Bangsa untuk memperkuat bahwa kegiatan tersebut menjadi landasan untuk terus ditingkatkan.

Dalam hal ini peran guru dan keterlibatan orang tua dalam mendukung program GLS ini sebagai bentuk perwujudan budaya baca bagi seluruh elemen dunia pendidikan. Dengan terus melakukan kegiatan One Book One Person sebagai pembentuk pendidikan karakter bagi peserta didik bersama guru dalam pengembangan budaya literasi. Salah satu strategi yang dilakukan sekolah adalah dengan membuat alur sosialisasi program perpustakaan, dengan cara :

Pertama, membentuk panitia GLS dari guru dan siswa (kepanitian OSIS) disekolah. Kepanitiaan GLS ini dibawah pengawasan sekolah, terutama kepala sekolah. Namun disini kepala sekolah juga terlibat dalam kegiatan membaca, dan kepala sekolah juga merupakan guru bersama siswa.

Kedua, melakukan strategi sosialisasi program tersebut secara terbuka kemudian membentuk team atau kelompok diskusi membaca. Kelompok ini terdiri dari guru dan beberapa orang siswa. Jumlah siswa disesuaikan dengan banyaknya guru yang tersedia disekolah.

Ketiga, mewajibkan setiap orang baik siswa dan guru memiliki 1 buku bacaan yang menjadi favoritnya. Buku-buku tersebut berasal dari milik sendiri. Namun untuk guru, disediakan buku yang sesuai dalam menunjang pengembangan diri dan karakter sebagai seorang guru atau peserta didik lainnya. Setiap orang membaca 1 judul buku selama 1 bulan selama 15 menit setiap pagi pada setiap harinya.

Keempat, melibatkan seluruh komponen sekolah terutama guru dan siswa dalam mendukung gerakan literasi sekolah. Selain itu melibatkan orangtua siswa yang diwakilkan oleh Komite Sekolah.

Kelima, Membuat papan afirmasi sebagai kalimat motivasi bersama dalam mengembangkan budaya baca. Serta menyediakan fasilitas lain 
dalam mendukung gerakan literasi disekolah. Seperti lokasi membaca yang berubah atau berpindah. Seperti membaca dikantin, perpustakaan, selasar, aula, dibawah pohon, taman sekolah, teras kelas, lapangan basket bahkan mushola.

Keenam, menentukan target/batas waktu buku bacaan yang sedang dibaca bersama, lalu menuliskan resensinya kedalam buku catatan. Hal ini dilakukan agar setiap siswa dan guru merasa memiliki sebuah tanggung jawab dalam menyelsaikan bacaan yang sudah disepakati bersama.

Ketujuh, mempresentasikan buku yang dibaca dengan gaya dan bahasa masing-masing. Hal ini dilakukan diantara kelompoknya secara bergiliran setiap minggu. Mekanismenya disesuaikan dengan banyaknya anggota pembaca.

Kedelapan, mengevaluasi kegiatan tersebut setiap $1 \mathrm{x}$ seminggu. Dan melihat perkembangan selanjutnya. Evaluasi dibagi berdasarkan kelompok siswa dan guru. Sehingga setiap guru dan siswa membaca bersama dengan kelompok kecilnya yang sudah dibentuk oleh panitia GLS.

Kesembilan, memberikan apresiasi (reward) kepada siswa yang aktif menyelesaikan bahan bacaannya dan memberikan resume terbaik dari tulisannya sendiri. Kemudian diumumkan secara terbuka, dengan tujuan memberikan motivasi kepada guru dan siswa lainnya.

Kesepuluh, mengumpulkan hasil tulisan dari pemikiran setiap pembaca, lalu kemudian tim panitia GLS menseleksi tulisan yang terbaik untuk dapat dipublikasi atau dicetak menjadi sebuah buku yang berasal dari pemikiran setiap peserta baik itu guru dan siswa. Dengan tujuan setiap bulannya ada hasil dari buah karya atas budaya membaca di sekolah.

Berdasarakan kesepuluh kegiatan dari One Book
One Person tersebut telah memberikan hasil positif terhadap pengembangan minat baca di sekolah Sukma Bangsa. Sampai saat ini sekolah tersebut terus menggalakan Gerakan Literasi Sekolah dengan rangkaian kegiatan berbeda namun tidak terlepas dari tujuan utama yaitu membaca.

\subsection{Faktor Pengaruh GLS Di Sekolah Sukma Bangsa Lhokseumawe}

Dalam pelaksanaan pengembangan budaya membaca melalui GLS ini diharapkan mampu mengatasi asumsi tentang rendahnya minat baca di Indonesia. Melalui kebiasaan membaca buku disekolah selama 15 menit secara tidak langsung akan menciptakan budaya baca dalam diri masingmasing. Meskipun untuk mewujudkan kebiasaan tersebut dalam penerapannya terdapat faktor pendukung dan penghambat selama kegiatan.

Jan Merse yang dikutip oleh (Hasbullah : 2015) menjelaskan bahwa penyebab keberhasilan dan kegagalan dalam impelemntasi kebijakan GLS disebagai karena beberapa faktor seperti adanya informasi yang jelas, kebijakan yang tegas, adanya dukungan dan adanya pembagian potensi dalam menerapkan kebijakan. Berdasarkan teori tersebut di atas dapat dijabarkan faktor pendukung dan penghambat GLS disekolah diantaranya :

a. Pendukung kegiatan terlaksana dikarenakan fasilitas sekolah yang begitu memadai dari segi letak dan nuansa bangunan sekolah sukma. Hal ini dapat dibuktikan dengan melihat luasnya area bangunan dengan jumlah 7,5 hektare. Serta keterlibatan stakeholder yang turut berperan aktif menggerakan siswa dan guru untuk terus membaca. Serta keterlibatan orangtua siswa sebagai pendukung eksternal dalam memberikan bantuan baik berupa motivasi dan promosi kegiatan disekolah. Kesiapan dan kerjasama tim GLS dalam rangka menyukseskan GLS disekolah.

b. Penghambat selama kegiatan GLS 
diantaranya ketergantungan dana yang berasal dari anggaran BOS serta padatnya jadwal kegiatan yang setiap bulannya berubah mengikuti program kegiatan sekolah seperti jadwal speaking english, yasinan, morning hope dan berbagai kegiatan bersama setiap paginya. Sehingga konsistensi Reading Day terkadang tidak terlaksana secara maksimal.

Dengan melihat beberapa faktor pendukung dan penghambat GLS, sekolah melakukan beberapa tindakan perubahan diantaranya :

a. Mengadakan lomba kegiatan yang berkenaan dengan literasi seperti duta baca, resensi buku dan workshop penulis serta mengundang mobil perpustakaan keliling.

b. Mendesain setiap pojok ruangan perpustakaan menjadi mini library dengan menyediakan buku-buku bacaan yang berasal dari sumbangan siswa, guru dan orang tua.

c. Melibatkan kegiatan literasi dalam berbagai kegiatan sekolah seperti school visit diluar sekolah serta memberikan apresiasi pada akhir semester kepada siswa yang aktif dalam mengikuti serangkaian kegiatan literasi. Contoh siswa peminjam buku terbanyak dan pengunjung terajin ke perpustakan.

d. Kolaborasi pustakawan bersama guru untuk terus aktif menghimbau dan menjadi role model bagi pengembangan pelaksanaan GLS disekolah.

e. Melibatkan orangtua siswa sebagai salah satu promotor pendukung GLS disekolah.

\section{Penutup}

One Book One Person merupakan strategi yang dilakukan dalam pengembangan Gerakan Literasi Sekolah dalam membudayakan membaca buku secara bersama-sama dan rutin. Gerakan literasi sekolah yakni membaca buku selama 15 meniti merupakan suatu usaha atau kegiatan yang bersifat positif dan partisipatif karena melibatkan guru dan siswa. Dengan adanya dukungan diantara keduanya, maka kegiatan yang digagas bersama akan meningkatkan minat membaca dan menjadi sebuah kebiasaan budaya membaca.

Gerakan Literasi Sekolah tidak akan berkembang andaikan hanya kewajiban membaca bagi peserta didik tidak dibarengi bersama guru sebagai pendidik. Dengan melakukan kolaborasi bersama dalam penerapan membaca nantinya akan memberikan dampak positif bagi keduanya. Membaca tidak hanya sekedar membaca kemudian menyelesaikannya tanpa ada hasilnya. Dengan melakukan beberapa strategi sebagai landasan dasar dalam mengembangkan budaya baca melalui One Book One Person, maka outputnya adalah bahwa setiap orang memiliki product dari hasil bacaannya.

\section{Daftar Pustaka}

Ahmad Baedowi, Direktur Pendidikan Yayasan Sukma, Jakarta. Sumber Media Indonesia, 11 Juli 2016.

Aziz, Moh.Saiful, Implementasi Kultur Literasi dalam Meningkatkan Kemampuan Membaca, Menulis dan Berpikir Siswa SD Plus Al-Kautsar Malang. Skripsi Jurusan Pendidikan Guru Madrasah Ibtidaiyah, Fakultas IImu Tarbiyah dan Keguruan, (Universitas Islam Negeri Maulana Malik Ibrahim Malang. 2017).

Endang Fatmawati. Mendongkrak Minat baca Melalui Gerakan Literasi. Dalam Buku Berjudul Membumikan Gerakan Literasi di Sekolah. (Yogjakarta : Ladang Kata, 2012.

Gewati, M, Minat Baca Indonesia Ada di Urutan ke -61 Dunia. http://edukasi.kompas.com/ $\mathrm{read} / 2016 / 08 / 29 / 07175131 / \mathrm{minat} . \mathrm{baca}$. Indonesia.ada.di.urutan.ke-60.dunia.

https://www.google.co.id/search?q=boarding+s chool+adalah\&oq=boarding +school $\& a q s=c h r$ ome.2.69i57j0l5.4849j1j7\&sourceid=chrome\&i e=UTF-8. 
Ikapi,4 Hal Yang Buat Jepang Punya Budaya Membaca. http://www.ikapi.org/kegiatan/item/172-4-halyang-buat-jepang-punya-budaya-membaca.

Imelda Aprilia. Pelaksanaan Program Gerakan iterasi Sekolah Guna Meningkatkan Budaya Membaca Siswa di SD Negeri 2 Limpakuwus. Program Studi Penididkan Guru Sekolah Dasar. Fakultas Keguruan dan IImu Pendidikan, Universitas Muhammadiyah Purwokerto, 2017.

Supandi, Menumbuhkan Budaya Literasi di Sekolah dengan Program Kata. 2016.

Http://simposium.gtk.kemdikbud.go.id/karya/files/ tendik1/SUPANDI.SPd.1811206090219.pdf. 